\title{
ALGUMAS REFLEXÕES SOBRE DESCARTES E MAQUIAVEL ${ }^{1}$
}

Cícero ARAUJO2

- RESUMO: Neste artigo, duas cartas de Descartes sobre Maquiavel são analisadas. Primeiro, é apresentado, com base no que o próprio filósofo sugere nas cartas, um contraste entre os dois pensadores, do qual emerge uma distinção entre moral e política em Descartes. Uma leitura da moral cartesiana é feita, em seguida, a fim de localizar as raizes desta distinção.

- PALAVRAS-CHAVE: Descartes; Maquiavel; moral; virtude; política; fortuna.

Comparar sempre envolve riscos de exagero. Quando se trata de comparar pensamentos filosóficos, o risco é maior ainda: a obra de um filósofo costuma ter muitas facetas em seus diferentes textos e mesmo num único texto. Assim, determinada faceta assemelha-se com uma qualquer de outro autor, enquanto em outra nada poderia haver de mais antagônico. Além disso, não se contempla a obra de um filósofo com os mesmos olhos. Não só porque o mesmo leitor modifica seu olhar com o tempo, mas também porque lá onde alguém vê "campo comum" entre autores - dependendo, é claro, do recorte que faz das obras, do que considera principal e secundário nelas -, sempre é possível haver quem veja um sumo contraste.

Ainda assim, parece-me que tal atividade acaba sendo extremamente elucidativa. Não raro, a comparação transforma nossa perspectiva de cada obra (aquela em que nos colocávamos quando a estudávamos separadamente): certos textos, frases ou até uma determinada palavra mudam de sentido ou mesmo passam a adquirir sentido.

Mas há comparações e comparações. Em alguns casos, a comunidade temática e de época são tão explícitas que tal atividade torna-se obrigatória: como pensar Platão

1. Este artigo é parte do trabalho final apresentado no Programa de Formação de Quadros Profissionais do CEBRAP, em abril de 1991.

2. Doutorando no Departamento de Filosofia - FFLCH - USP - 05508-900 - São Paulo - SP. 
sem que a figura de Aristóteles nos venha à cabeça? Mas há casos em que as preocupações são aparentemente tão discrepantes - sem contar a separação de época -, que um empreendimento de comparação não deixaria de ser de qualquer ponto de vista, bastante temerário.

Parece ser o caso de Descartes e Maquiavel. Embora a Europa culta do século XVII já tivesse amplo conhecimento da obra do pensador florentino, inclusive traduzida para o francês, nada dos textos de Descartes destinados à publicação indica qualquer tentativa de diálogo com Maquiavel. É como se o desconhecesse completamente.

Nada a estranhar, porém, se este desconhecimento fosse real: afinal de contas, os grandes empreendimentos políticos e as intrigas dos soberanos sempre estiveram fora de suas cogitações, e de forma deliberada. Tendo a crer mesmo que ele jamais teria se aventurado a cotejar o pensamento de Maquiavel com o seu próprio, não fosse o apelo de uma ilustre amiga, a princesa Elisabeth, que, depois de três anos de assídua correspondência debatendo os escritos cartesianos (um dos quais, os Principes de la Philosophie, dedicado a ela), pedia-lhe então para escrever sobre "as máximas da vida civil". ${ }^{3}$ Cedendo aos seus apelos, tempos depois, como mote da discussão, ambos combinam a leitura de $O$ Príncipe.

A jovem Elisabeth - cujo pai, Frederico, fora rei da Boêmia - encontrava-se, na época, exilada na Holanda com sua família em virtude da Guerra dos Trinta Anos. Em sua correspondência com Descartes, por mais de uma vez ela se queixara dos infortúnios políticos de sua família, que tanto a afligiam física e emocionalmente. Mas as queixas logo se transformavam num diálogo restrito ao tema da felicidade pessoal que, aos olhos de Descartes - como veremos com mais detalhes oportunamente -, independia de infortúnios daquele tipo. Sobre o tema da felicidade, por sinal, a princesa já lhe havia pedido para escrever algo inspirado em um livro de Sêneca (não raro os ensinamentos de Descartes a Elisabeth eram expressos na forma de comentários de livros que ambos combinavam de ler).

Contudo, ao solicitar suas opiniões sobre "as máximas da vida civil", a moça sabia que avançava sobre um terreno delicado, estranho aos termos com os quais até então haviam se desenrolado as conversas com Descartes, e que tinha um certo ar desafiador, porque o próprio Descartes havia declarado várias vezes, em escritos públicos e a ela pessoalmente, sua aversão ao assunto, que dizia respeito exclusivamente aos soberanos. Ainda que com certa hesitação, acaba aceitando dar sua opinião, em uma carta datada de setembro de 1646. Elisabeth responde no mês seguinte; por fim, numa carta de novembro do mesmo ano, Descartes dedica algumas poucas linhas mais sobre o tema e, aparentemente, encerra a discussão. É a essas cartas que nos dedicaremos agora, para verificar se dali seria possível extrair elementos de um pensamento político como, de resto, vários comentadores já sugeriram. ${ }^{4} \mathrm{O}$

3. Carta de Elizabeth a Descartes, abril de 1646.

4. Cf. os artigos de Polin (1987), Goyard-Fabre (1973) e Regnault (s.d.). 
contraponto com Maquiavel, indicado pelas próprias cartas, servirá como uma referência de apoio a essa reflexão.

\section{II}

Ao ler as duas cartas sobre Maquiavel, isoladas do conjunto da correspondência entre Descartes e Elisabeth, é tentador dar tal importância ao seu conteúdo a ponto de se querer extrair dali os fundamentos de uma filosofia política cartesiana. Exatamente pelo fato de constituírem um dos raríssimos momentos em que Descartes se dispõe a falar da política dos Estados.

A tentação pode ser mitigada se pensarmos, em primeiro lugar, que se trata de um ponto de descontinuidade: o assunto não faz parte da reflexão sistemática do filósofo - sistemática, pelo contrário, é sua recusa em erigir uma filosofia política -, desvia-se do caminho que persevera nas demais cartas que compõem a correspondência com a princesa e no conjunto dos textos destinados à publicação. ${ }^{5}$ Em segundo lugar, o próprio Descartes deixa claro, nas duas cartas, que vai falar como um leigo no assunto (ao contrário das cartas que tratam de Metafísica, Medicina e Moral), e chega mesmo a declarar que não pretende ensinar qualquer coisa à princesa sobre "esta matéria" e sim proporcionar-lhe "algum divertimento". Isso, apesar da relativa extensão dos comentários (especialmente na primeira carta) e da gravidade com que aprecia os ensinamentos de Maquiavel.

As primeiras experiências de leitura desses textos alternaram em mim a inclinação para considerá-los mais uma peça de crítica severa aos escritos do florentino - como os muitos versus machiavellum (em geral de caráter moralizante) que se difundiram na Europa desde a primeira hora em que se tornaram públicos; ${ }^{6}$ ou, ao contrário, a inclinação para reconhecer, afinal, uma sintonia essencial entre Descartes e Maquiavel. Pensei no que poderia haver neles que suscitava em mim tendências tão contrárias.

A primeira carta ${ }^{7}$ - a mais extensa - começa com o próprio Descartes indicando uma oscilação: comentando O Príncipe, diz que encontrou nele preceitos "muito bons" e outros que "não poderia aprovar". Mas a primeira crítica não poderia ser mais veemente: diz que o "maior erro" cometido pelo autor foi não ter distinguido claramente entre príncipes que "adquiriram um Estado por vias justas e aqueles que o usurparam por meios ilegítimos". Assim, Maquiavel teria equivocamente generali-

5. As citações das cartas e livros de Descartes referem-se à edição francesa de F. Alquié (1983; abreviatura utilizada: $D A$, seguida pelo número do tomo em algarismo romano e o número da página). Eventualmente, à edição C. Adam e P. Tannery (1966; abreviatura: AT). Em algumas passagens, vali-me da tradução de B. Prado Júnior e J. Guinsburg da Obra escolhida de Descartes, 1973.

6. Ver, a respeito, Lefort (1972, p. 96, 104).

7. DA III, p. 665-71. Em várias passagens desta carta, vali-me da tradução de C. A. Ribeiro do Nascimento, 1984. 
zado preceitos adequados apenas aos últimos; em relação a estes, de fato, a marca registrada só poderia ser a violência, pois "aqueles que começaram a se estabelecer por meio de crimes são obrigados ordinariamente a continuar a cometer crimes e não poderiam se manter se quisessem ser virtuosos".

Só que Descartes se restringe a apontar a necessidade da justiça na aquisição do Estado (é necessário "supor que foram justos os meios de que ele [o príncipe] se serviu para estabelecer-se"). Mas não diz uma palavra sobre o conteúdo desse princípio. Inclina-se, pelo contrário, a subjetivá-lo: entende por "meios justos", "quase todos os meios" ao alcance dos príncipes, desde que estes os "julguem tais". O que se explica na idéia de que o soberano está acima da justiça "entre os particulares"; além disso, "parece que nestas ocorrências Deus dá o direito a quem dá a força". Para Descartes, o problema todo está, não no que se entende objetivamente por justiça, mas na intenção do sujeito que a dá: "as mais justas ações se tornam injustas quando os que as fazem as pensam tais".

Contudo, isso não significa, como pode parecer à primeira vista, uma aceitação da doutrina do direito divino dos reis: o martelo de Deus apenas decreta a relação necessária entre quem tem a força e o direito de dar a justiça, mas não que Ele tenha ungido determinadas pessoas, muito especiais, para governar. Tanto que Descartes considera legítimos até mesmo os príncipes "recentemente entrados num Estado" os que de "particulares" passaram à condição de governantes (alusão aos "príncipes novos" de Maquiavel). A legitimidade não consiste na identificação do legítimo herdeiro mas, a esta altura da carta pelo menos, é o resultado da intenção de se fazer justiça. Termo que, aliás, ganha maior sentido quando nos remetemos a outros textos do filósofo.

Descartes já havia dito a Elisabeth - e também o dirá à rainha Cristina da Suécia - que a felicidade é alcançada não tanto pela correta adequação (feita pelo entendimento) dos meios aos fins.

O entendimento deve, sim, guiar nossas ações - a virtude não é pura vontade de fazer o bem, e não há virtude sem a intervenção do entendimento; todavia, mesmo que o entendimento erre (desde que, evidentemente, nos esforcemos por usá-lo), ainda assim a felicidade está ao alcance de todos. Pois, consistindo a felicidade na aquisição do Bem Soberano; e não sendo este outra coisa senão o "contentamento do espírito" resultante da prática da virtude, isto é, da "vontade firme e constante de que julgamos ser o melhor"; 8 então fazer o bem nada mais é do que ter a intenção de fazer o bem com o uso do entendimento. Se considerarmos a justiça um bem, a mensagem da carta se esclarece imediatamente.

O problema é que Descartes, quando fala do Bem Soberano, fala no plano privado. Nada nos esclarece a respeito do que poderia ser o Bem Soberano na esfera pública. Aliás, na carta à rainha Cristina, chega a distinguir os dois: o Soberano Bem "de cada

8. DA III, p. 598, 746; cf. também passagem das Passions de l'âme, DA III, p. 1064. Referências a esta última citação serão a partir de agora abreviadas por $P A$, seguida pelo número do artigo. 
um em particular [que é o assunto da carta] é toda outra coisa" do Soberano Bem "de todos os homens em conjunto" (DA III, p. 746). Admitamos que o príncipe seja pessoalmente feliz se praticar a vertu cartesiana: mas isso garantirá a sobrevivência do Estado, a manutenção do "bem público" ou mesmo a sua permanência enquanto soberano? A vertu cartesiana é apropriada a quem pretende conquistar o poder ou conservá-lo? Descartes parece não ter em mente essas questões até aqui, ou, se as tem, limita-se a apontar uma secreta convergência entre a eficácia da ação do príncipe (o que significa ser bem-sucedido nos negócios do Estado) e a intenção de fazer justiça.

Com isso o filósofo exime-se de rastrear qualquer teoria da justiça universalmente válida (no caso do cartesianismo, leia-se: metafisicamente garantida). E a tentativa de estabelecer preceitos com base na idéia da intenção esgota-se nela mesma. Descartes é então levado a considerar as demais partes do livro de Maquiavel, colocando entre parênteses o componente intencional de sua vertu, para explorar 0 que se refere ao uso do entendimento. Diferentemente do campo do conhecimento científico, o uso do entendimento no campo da ação chama-se "prudência", o que significa guiar-se mais pela "experiência" do que pela intuição de idéias claras e distintas (DA III, p. 654) - intuição, aliás, impossível num espaço em que corpo e alma encontram-se substancialmente unidos -, e se contentar com o verossímil, em "julgar o melhor possível". Vejamos como explora esse componente.

Da mesma forma que Maquiavel ${ }^{9}$ o filósofo divide o assunto em três aspectos: política para os "inimigos", para os "aliados ou amigos" e para os "súditos". Em relação aos primeiros, acolhe a metáfora do acoplamento da raposa ao leão (astúcia e força; Maquiavel usa a imagem no capítulo 18, mas nesta altura ele já está tratando dos dois últimos aspectos): contra os inimigos é permitido "quase tudo". Chega a admitir até uma definição bem ampla destes: "compreendo, sob o nome de inimigos, todos os que não são amigos ou aliados, pelo fato de que se tem direito de lhes fazer guerra quando nisto se encontra nossa vantagem".

Mas o tom crítico reaparece quando o assunto passa a ser a relação com os "amigos ou aliados". Neste caso, pensa Descartes, o tratamento deve ser totalmente diferente: "a amizade é uma coisa demasiado santa para dela se abusar", diz, referindo-se à passagem de $O$ Príncipe que recomenda, em certos casos, a simulação da amizade com o propósito de arruinar um aliado. Contudo, o que faz Descartes recusar esse conselho é menos o valor em si da amizade do que as conseqüências práticas de uma atitude desleal. Pois, mesmo que o cumprimento da palavra dada, por exemplo, fosse prejudicial a curto prazo, "não o poderia ser tanto quanto lhe é útil a reputação de não deixar de fazer o que prometeu" (o grifo é meu). Repare-se como a ênfase da análise desloca-se da intenção do sujeito para a sua imagem (o que os "outros" pensam de seu caráter). O que leva Descartes a dar uma delimitação mais precisa do campo dos "aliados", chegando mesmo a descolorir o tom da crítica a

9. As referências a O Príncipe são da tradução brasileira de Livio Xavier (Maquiavel, 1987), identificada neste artigo com a letra $P$. 
Maquiavel: assim, pensa o filósofo que a vigência do preceito da lealdade só é possível quando o príncipe mantém "alianças estreitas" apenas "com aqueles que são menos poderosos", pois estes sempre temerão trai-lo. Ora, com tal restrição, o próprio Maquiavel admitiria a importância de preservar aliados com a fidelidade.

A crítica abranda mais ainda quando o assunto é a política para os súditos. Descartes já havia elogiado a idéia de que "o amor do povo vale mais que as fortalezas" (referência a Maquiavel, 1987, cap. 20). Agora ele vai concordar com a classificação maquiaveliana de dois tipos de súditos - os "grandes" e o "povo" (cf. $P$, cap. 9). E a definição de cada tipo não parece muito diferente: "grandes" são "todos aqueles que podem formar partidos contra o príncipe"; "povo" é o resto, a maioria quantitativa. Mas Descartes deixa de considerar o conflito entre os dois grupos (implicíto na própria definição maquiaveliana desses termos: "grandes" são os que querem oprimir 0 "povo"; "povo", os que não querem ser oprimidos), que é um dos pontos centrais da análise de Maquiavel em todo o livro, para apenas considerar o conflito potencial de cada grupo contra o soberano. E, por esta ótica, Descartes dá preceitos quase idênticos aos do pensador florentino: quanto aos "grandes", "todos os políticos estão de acordo que se deve empregar todos os cuidados para rebaixá-los" (comparar com $P$, cap. 3); mas no que toca ao "povo", "deve-se sobretudo evitar seu ódio e desprezo" (comparar com P, cap. 20).

Agora, quanto à maneira de evitar o ódio, o filósofo, mesmo ao estar em sintonia com Maquiavel, parece raciocinar mais linearmente, retirando a sinuosidade dos conselhos deste: por exemplo, quando diz que o príncipe sempre deveria observar a "justiça à moda deles" (dos súditos), o que Maquiavel admite para o caso dos "principados mistos" (cf. $P$, cap. 3, 5), mas não quando o príncipe é inteiramente novo e é obrigado a refundar o Estado (cf. $P$, cap. 6). De qualquer forma, Descartes retém a idéia da reputação do príncipe perante os súditos, e é em tal medida que diz que vale até mesmo o sacrifício da transparência de suas ações: assim, o soberano deve recorrer a seus ministros e auxiliares, encarregando-os "das condenações mais odiosas", reservando para si "suas ações mais sérias ou aquelas que podem ser aprovadas por todos" (comparar com $P$, cap. 7, em que Maquiavel extrai esta lição das peripécias políticas de César Bórgia).

Ainda que concordando com o conselho da preservação da imagem, Descartes prepara aqui o terreno para uma nova crítica. Se a imagem é tão essencial, o é também, por decorrência, ser "imutável e inflexível" nas decisões. Pois uma atitude assim, por mais prejudicial que venha a ser, nunca será maior que "a reputação de ser leviano e instável" (o grifo é meu). Apesar de Maquiavel também observar isso quando critica os "príncipes irresolutos" (cf. $P$, cap. 21, 23), Descartes acredita que há aqui uma contradição no pensamento do florentino; ser "imutável e inflexível" nas decisões se chocaria com a máxima do capítulo 15, que recomenda ao príncipe "ser malvado quando a ocasião o exigir" (pois, diz Maquiavel, "sendo o mundo muito corrompido, é impossível que não nos arruinemos se quisermos ser sempre homens de bem"). Ora, para Descartes é evidente que, desde que consideremos "homem de bem" aquele que 
"faz tudo o que lhe dita a verdadeira razão" - e não aquele "homem supersticioso e simples, que não ousa ferir batalha no dia de Sabá" -, "o melhor é esforçar-se por sê-lo sempre". Com isso, salvar-se-ia a máxima da imutabilidade nas decisões.

Mas não é apenas a coerência das máximas que poderia ser salva. O filósofo quer também, a esta altura, resgatar uma idéia que sugerira no início da carta: é possível conciliar o princípio de "fazer o bem sempre", com a necessidade de agir com eficácia, no sentido de o príncipe conservar sua posição. Tanto é assim que vai discordar enfaticamente de uma passagem do capítulo 19: "o príncipe pode se arruinar tanto pelas boas quanto pelas más ações" asseverando, ao contrário, que o príncipe deveria praticar "boas ações" sempre, pois estas só tenderiam a conquistar mais e mais o amor do povo. E mesmo que a "boa ação" eventualmente prejudicasse particulares, não haveria razões para crer que ela se converteria em ódio: "sofre-se com paciência os males que não merecemos quando se crê que o príncipe, de quem os recebemos, é de algum modo obrigado a fazê-los e que tem desprazer nisto, pelo fato de que se estima que é justo que ele prefira a utilidade pública à dos particulares".

Descartes, porém, tem plena consciência de que nem sempre os súditos concordam com o príncipe sobre o que é "fazer o bem", mesmo quando ambos têm em mira a "utilidade pública". Isso fica claro quando considera o caso em que a opinião do povo sobre a justiça não é unitária - por exemplo, quando os "civis" têm uma opinião e os "soldados" outra: "Neste caso, é razoável conceder alguma coisa a uns e outros." O que põe em relevo o viés pragmático, não-categórico, do preceito "fazer o bem sempre", que havia lapidado nas linhas anteriores.

Atente-se que neste ponto Descartes resgata também a idéia inicial de que não há nenhum princípio objetivo de justiça que possa definir claramente, por exemplo, o que seria o "bem comum" ou a "utilidade pública". Apenas diz que cada povo, país ou Estado tem o seu princípio, que é todo particular, ao qual o príncipe deve estar atento para dele lançar mão em seu proveito, sem que desperte o ódio do povo. E já que esta é a forma que mais prescinde do uso da violência, Descartes vai considerá-la a mais conveniente para o príncipe assegurar-se, ainda que tenha que gastar boa parte de seu tempo inculcando nos súditos a justiça "a seu modo". Pois "pouco a pouco" graças à atividade educadora dos "escritos públicos" e da "voz dos pregadores" - os súditos saberiam concebê-la por conta própria.

\section{III}

Todo esse movimento oscilante da carta, até aqui pelo menos, bem poderia indicar o esforço de Descartes para conciliar elementos fundamentais de sua moral cujo objetivo é a felicidade "de cada um" - com preceitos adequados a um soberano que norteia suas ações no sentido da conservação do poder. Como se estivesse com um pé "fora" e outro "dentro" da quadra do jogo de política que Maquiavel queria 
seduzir seu leitor a jogar: de "fora", diz que ele não pode ser jogado sem o princípio da justiça (que é o que regeria a divisão entre príncipes "legítimos" e "ilegítimos"), mas elude o problema teórico, subjetivando o princípio - a justiça é aquilo que o soberano considera justo. Por "dentro" da quadra, suspende o problema da intenção de justiça do príncipe para pôr o acento na reputação de ser justo. E ficamos sem saber se a justiça praticada (isto é, a justiça "à moda do povo") deveria ou não coincidir com o que, intimamente, o governante entende por justo.

Esse esforço, porém, sofre uma súbita interrupção no final da carta, quando Descartes - como que sentindo que o "divertimento" que estava propiciando à princesa já ia longe demais - passa a questionar a própria validade de se estabelecer máximas aos soberanos. A oportunidade do questionamento surge exatamente no momento em que vai comentar o Prefácio-dedicatória de O Pńncipe a Lorenzo de Médicis (soberano de Florença). Diz achar inconveniente a imagem que Maquiavel utiliza para justificar seu trabalho ("assim como é preciso estar na planície para ver melhor a forma das montanhas, também é necessário ser de condição privada para conhecer bem o ofício de um príncipe"). Seu argumento: "os principais motivos das ações dos príncipes são muitas vezes circunstâncias tão particulares que, a não ser que se seja o próprio príncipe ou então que se tenha sido por longo tempo participante de seus segredos, não se poderia imaginá-los". Assim, "mereceria ser objeto de zombaria se pensasse poder ensinar alguma coisa a Vossa Alteza nesta matéria".

Mais interessante ainda é que neste trecho final o filósofo acha oportuno lembrar à princesa uma lição anterior: que não devemos vincular nossa felicidade pessoal às peripécias da fortuna - sinalizando que o assunto guardava alguma dependência com ela - e que o melhor para a princesa seria "resolver praticar aquelas máximas que ensinam que a felicidade de cada um depende de si mesmo". E para alguém como ela, nascida em berço esplêndido, mas que agora amargava os dissabores do exílio exatamente por fazer parte de uma família real, em que os problemas políticos de seu país e os familiares se misturavam tanto -, aquele preceito significava, talvez até com mais intensidade do que para os que sempre viveram no infortúnio, considerar aquelas razões "que servem para fazer com que aprovemos as coisas que vemos acontecer".

Com essas observações, seria o caso de nos perguntarmos se, nesse trecho final da carta, Descartes não estaria concedendo uma espécie de liberação das já frágeis amarras moralizantes com que, linhas acima, vinha tentando restringir as ações dos soberanos; e se não seria também uma admissão de que os ensinamentos sobre a felicidade pessoal não guardam relação necessária com os procedimentos próprios de um chefe de Estado. A carta seguinte, de novembro de 1646, só vai acentuar esta impressão. Mas antes de falar sobre ela, vejamos como a princesa responde à primeira carta (ATIV, p. 519-24). Diz ela que, quando lera O Príncipe, havia experimentado uma aprovação geral de seus preceitos, "não por serem bons em si, mas porque causam menos mal". E que achou-os melhor do que os de que costumam se servir inúmeros "ambiciosos imprudentes"; pois se estes tendem a causar a ruína, aqueles pelo menos "tendem todos ao estabelecimento". Lembra, além disso, que o objeto principal do 
livro é "o Estado mais difícil de governar, onde o príncipe é um novo usurpador". Neste caso, "as grandes violências fazem menos mal que as pequenas". Justamente por se tratar de uma circunstância específica, a princesa diz concordar com a crítica de seu correspondente: Maquiavel propusera como gerais, máximas que seriam próprias apenas naquelas circunstâncias. Contudo, diz ela, no mesmo erro incorreram "quase todos os Santos Padres e os antigos filósofos" (só que em relação a outras circunstâncias).

Quanto ao problema de "fazer o bem sempre" ou não, pareceu à princesa que Maquiavel se referia não tanto ao homem supersticioso (talvez lhe tenha parecido que Descartes havia dito isso na carta), mas ao que segue "esta lei comum" que reza ser necessário "fazer a cada um como se quisesse fazer a si", princípio que o soberano não poderia seguir "quase nunca", pois assim requer "a utilidade pública". Não via nisso um problema, desde que se definisse claramente "virtude" como seguir o que a reta razão determina, e não restringi-la a certas "leis ou regras particulares". Definição que, segundo a princesa, não havia sido explicitada por ninguém antes de Descartes.

A princesa encontrará na resposta do amigo um escritor bem menos disposto a se alongar no assunto. Descartes se limitará a dizer que Elisabeth "assinalou muito bem seus erros [os de Maquiavel] e os meus; pois é verdade que seu propósito de louvar César Bórgia o fez estabelecer máximas gerais para justificar ações particulares que dificilmente poderiam ser executadas". E registra que havia lido, depois, "seus discursos sobre Tito Lívio, onde não observei nada de mal". Registra, também, sua aprovação ao que considerará o "principal preceito" do livro: deve-se "extirpar inteiramente os inimigos, ou então tornar-se seus amigos, sem jamais seguir a via do meio".

Apesar da aprovação, Descartes faz o seguinte reparo, a meu ver bastante significativo se levarmos em conta aquela súbita mudança de curso que o final da outra carta havia empreendido: diz que, mesmo sendo o preceito dos Discorsi "sem dúvida o mais certo", "não é o mais generoso", quando "não temos nenhum motivo de temor" (o grifo é meu). Ora, apesar de toda a relutância com que Descartes parece escrever essas linhas, admitir que determinado comportamento político é o "mais certo" e, ao mesmo tempo, não necessariamente qualificável como "generoso", parece indicar a concessão de que a virtude cardeal de sua moral não seria presença obrigatória no campo de atividades de que trata Maquiavel.

A palavra "generoso" é usada por Descartes com um sentido bem determinado. Trata-se de uma especificação de sua definição geral de virtude: "a verdadeira generosidade", diz o filósofo nas Passions de l'âme consiste, por um lado, em conhecer que nada pertence tanto a alguém como a "livre disposição de suas vontades", e, por outro, o sentimento de uma "firme e constante resolução de bem usá-la", isto é, de "nunca carecer de vontade para empreender e executar todas as coisas que julgue serem as melhores; o que é seguir perfeitamente a virtude" (PA, art. 153). A generosidade, em conseqüência, "impede que se despreze os outros", pois nos faz 
pensar que aquele "conhecimento e sentimento de si próprios" não se restringe a nós mesmos, mas deve estar presente nos demais homens. Assim, sempre tenderemos a desculpá-los por suas faltas, já que estimaremos que as cometeram, não por falta de vontade, mas por "falta de conhecimento". E se a "boa vontade" pode existir em cada um dos outros homens, então nunca nos consideraremos "muito inferiores aos que possuem mais riquezas e honras", nem "muito superiores" aos que possuem menos (PA, art. 154). Não é por acaso, a seu ver, que "os mais generosos" tendem a ser "os mais humildes" (PA, art. 155) e nada estimem mais do que fazer o bem aos outros e "desprezar seu próprio interesse" (PA, art. 156).

Desde que se tenha o conhecimento de certos bens fundamentais, toda ênfase da moral cartesiana recai, portanto, no esforço da vontade. Aliás, como está fundado metafisicamente o conhecimento de que a alma "é mais nobre que o corpo", isso implica que o maior bem que possuímos "é a livre disposição de nossa vontade" ( $P A$, art. 144). O problema moral decisivo é então o controle que a vontade deve exercer sobre a paixão do desejo, paixão que tende a embaçar a fronteira entre o que está ao nosso alcance e o que não está. E a virtude da generosidade, transformada em hábito, é um excelente "remédio" contra os "desregramentos" do desejo. ${ }^{10}$

Tentemos agora contrastar essa concepção de "generosidade" com as lições que Descartes diz ter extraído da leitura dos Discorsi sopra la prima deca di Tito Livio. ${ }^{11} \mathrm{E}$ simples perceber por que o filósofo registrou uma dissonância entre as máximas daquele livro e seu ideal do homem "generoso". Particularmente elucidativa é a passagem em que Maquiavel faz uma primeira análise dos tipos de constituição das repúblicas (D I, cap. 1-6). Ancorando-se nos exemplos de Esparta, Veneza e Roma, diz que o tipo de constituição condiciona e é condicionado pela política externa: Esparta teve sua constituição feita de uma só vez e definitivamente por Licurgo e excluía os "estrangeiros" da cidadania; Esparta e Veneza tinham regimes "aristocráticos", excluíam a plebe do poder. Já Roma tinha sua constituição freqüentemente modificada, e era marcada por fortes tensões entre a nobreza e a plebe; esta última participava do poder, impôs à nobreza a instituição do tribuno e o direito de escolher os cônsules; além disso, Roma era uma cidade aberta aos "estrangeiros" ( $D$ I, cap. 5-6). Distintas características constitucionais levaram a distintas políticas externas: Esparta e Veneza limitaram-se a políticas pouco agressivas, de conquistas moderadas. E toda vez que fizeram guerras de maior envergadura se arruinaram, ou porque não reuniam força suficiente para a vitória, ou porque não conseguiam preservar as

10. Digo transformada em hábito porque Descartes considera que a paixão, o mais claro signo da união substancial do corpo e da alma, quando desregrada, nunca poderá ser combatida com eficácia, apenas pela "ação da alma" (da vontade). Há que se contrapor paixão e paixão - a vontade cria, por educação, uma espécie de hábito apaixonado que aciona um mecanismo psicofísico análogo, mas de efeito contrário, ao da paixão do desejo: assim, se nos habituarmos a considerar as vantagens do livre-arbitrio e "quão inúteis e vãos são todos os cuidados que afligem os ambiciosos", podemos "excitar em nós a paixão e em seguida adquirir a virtude da generosidade, sendo esta como que a chave de todas as outras virtudes" (PA, art. 161).

11. As citações dessa obra (a partir de agora identificadas com a letra $D$ ) foram extraídas da tradução brasileira de Sérgio Bath. 
conquistas. Roma, ao contrário, desde o começo enveredou pelo caminho da extrema agressividade, lançando-se à construção de um império. Sua Constituição era incompatível com a modéstia de pretensões. Uma conseqüência direta da abertura política à plebe e aos "estrangeiros", pois sua contrapartida tinha que ser a busca constante de riquezas de outros Estados (D I, cap. 6).

Maquiavel procura mostrar então que o exemplo de Roma não permitia aquilo que tradicionalmente se admitia como "justa medida" no trato com as riquezas (isto é, o meio termo entre a falta e o excesso). Nem sempre o que vale para o cidadão individualmente - a moderação para preservar a ordem da cidade - vale para o Estado, principalmente se é uma república. Para esta, ao contrário, a característica "mais gloriosa", e que funciona como um estímulo à vida civil republicana, é a ambição, a opção pelo excesso ( $D$ I, cap. 6).

Numa outra passagem, retomando o que havia dito em O Príncipe, Maquiavel considera as atitudes que devem ser tomadas por um "novo soberano". Este, a seu ver, não pode relutar um só minuto em adotar um modo de agir "bárbaro, contrário à civilização, anticristão e anti-humanitário", quando necessário. Mas não se pense que o maior obstáculo à adoção desse comportamento é exterior ao protagonista. A grande batalha que todo "novo soberano" vai travar é contra uma tendência profundamente encravada em si próprio: os homens "pensam que é possível escolher um caminho entre esses dois extremos, o que é muito perigoso. Não sabem ser completamente bons nem completamente maus". Mas a quem "em vez do bem preferir o poder", convém que opte por atitudes extremas (D I, cap. 26; comparar com P, cap. 3). Por isso Roma "nunca tomou meias-medidas": ou tornava-se inteiramente amiga de outros povos - "concedendo-lhes privilégios, cidadania, completa segurança" -, ou tornava-se inteiramente inimiga, sendo "suas casas devastadas" e "dispersos de modo a não poder causar mais dano" ( $D$ II, cap. 23).

Justamente a crítica à via del mezzo que Descartes havia registrado e, surpreendentemente, aceito. Digo "surpreendentemente" porque todas as restrições que Descartes havia feito a O Príncipe, na primeira carta, poderiam ser feitas aos Discorsi, na segunda. Como acabamos de ver, também nesta obra o florentino aconselha ao chefe de Estado não ser "homem de bem sempre"; prega a necessidade de esconder suas verdadeiras intenções (cf. $D$ I, cap. 44) e o uso da fraude ( $D$ II, cap. 13); e dá exemplos de como ele pode se perder tanto por "boas" quanto por "más ações. ${ }^{12} \mathrm{E}$, todavia, Descartes diz que nos Discorsi não encontrara "nada de mal".

Parece-me evidente que para o filósofo essas considerações contra as "meiasmedidas" são bem pouco compatíveis com a ação generosa, modelo de sua moral. Foi exatamente isso que Descartes quis assinalar na carta: por mais flexível que fosse sua definição de "generosidade", nem de longe seria possivel apontar uma conver-

12. Cf. a comparação entre os comportamentos de Anibal e Cipião em Maquiavel, 1979, v. 3, cap. 21; por sinal, o mesmo exemplo dado em Maquiavel, 1987, cap. 17. 
gência entre ela e o que Maquiavel chama de "bárbaro, anticristão e anti-humanitário". Ao mesmo tempo, Descartes diz que o preceito maquiaveliano é "sem dúvida o mais certo". Estaria o filósofo deliberadamente se contradizendo para evitar um conflito de opiniões com Elisabeth? Talvez. Contudo, mesmo tal comportamento só parece inteligível se projetado sobre o pano de fundo da recorrente recusa de trazer a política para sua reflexão filosófica.

Enfim, tudo isso me fez considerar seriamente a hipótese de que Descartes estaria, na segunda carta, reconhecendo a incompatibilidade entre os princípios que regem a vida de um "particular" e os que regem a de um homem de Estado; e que talvez essa seria a única questão em que os dois autores convergiriam inteiramente. Como duas retas que se encontram num único ponto para logo em seguida seguirem seus próprios caminhos.

E o caminho seguido por Descartes nessa segunda carta não poderia ser mais claro. Exceto essas poucas referências aos Discorsi, a carta retoma a atenção ao bem-estar privado. A princesa é então advertida de que os livros "desse Doutor dos Príncipes" só tenderiam a afastá-la do desfrute das "coisas presentes" e lhe causar tristeza; pois Maquiavel, "não representando senão as dificuldades que eles [os príncipes] têm para se manter, e as crueldades e perfídias que lhes aconselha, faz com que os particulares que o leiam tenham mais motivos para invejar sua condição, do que para a lastimar".

Fica bem visível aqui o entrelaçamento entre Medicina - "técnica que visa ao corpo" - e Moral - técnica "que só visa ao corpo enquanto associado em mim a um entendimento puro"13 -, pois Descartes acreditava que as doenças corporais de que a princesa freqüentemente se queixava eram derivadas de estados de alma nocivos. Daí que procurasse modificar tais estados na princesa induzindo-a a pensamentos "alegres" ou ajudando-a a pensar o "lado bom", mesmo de situações trágicas como a morte por decapitação de seu tio, o rei Charles I da Inglaterra: sua morte, escreve a Elisabeth, apesar de violenta, fora "mais gloriosa, mais feliz e mais doce" do que se tivesse ocorrido "em seu leito", e até menos dolorosa se tivesse sido por uma "doença que mata vagarosamente" (DA III, p. 889).

Descartes também sabe que uma das causas do abatimento da princesa, filha de ex-soberanos, é a Guerra dos Trinta Anos, que arruinara sua família. Não me parece acidental que ela se identifique tanto com o ponto de vista de Maquiavel: a Alemanha do século XVII bem poderia lhe sugerir a Itália do século XVI: "sem chefe, sem ordem, batida, espoliada, lacerada, invadida" (como diz Maquiavel no último capítulo de $O$ Príncipe), em suma, inteiramente à mercê de potências estrangeiras (entre elas, as mesmas França e Espanha, que compõem muitas das cenas políticas descritas pelo florentino).

13. Cf. Gueroult, 1968, v. II, p. 220. Sobre a relação entre Medicina e Moral em Descartes, ver os capítulos XIX e XX da mesma obra. Ver, também, Teixeira, 1990, p. 129-30. 
Assim, tendo em mente o contexto que cercava sua "paciente", Descartes percebera a necessidade de uma intervenção cirúrgica bem precisa: desvincular, nos pensamentos da princesa, a felicidade da pátria da felicidade pessoal.

\section{IV}

Procuramos mostrar, até aqui, que a filosofia cartesiana tolera muito bem a divergência entre os princípios da vida privada e os da vida pública. O que introduz uma séria dificuldade na tese de que o filósofo, nas cartas à princesa, teria pensado a política inseparavelmente da moral, ${ }^{14}$ pelo menos no sentido em que entende essa última.

Ao invés de se buscar tal elo, a mim parece mais promissor pensar por que Descartes não reservou um lugar especial para a política, embora o tenha reservado para a moral. Não digo que ele tenha se recusado a agir politicamente, o que é desmentido por sua própria vida. Mas penso que há fortes razões para supor que ele não concedeu dignidade filosófica à política. E como essa tendência não é de todo inusitada na história da filosofia (embora rara ou pouco conhecida nos autores hoje tidos como "clássicos"), vale a pena pesquisar suas fontes. ${ }^{15}$

Em relação a Descartes, especificamente, uma das várias maneiras de abordar o problema seria se perguntar por que sua filosofia abriu a possibilidade de pensar a felicidade pessoal (o tema da moral) mas fechou-se para o tema da felicidade pública. Creio que uma resposta possível está no fato de Descartes ter vislumbrado o fio que conduzia a moral à sua metafísica, mas não o encontrou nem para a ética (isto é, a investigação sobre as "leis e os costumes dos povos"), nem para a política em sentido estrito (a investigação sobre a prática dos agentes políticos).

Um dos textos mais interessantes para investigarmos isso, como não poderia deixar de ser, é o Discours de la méthode. Em consonância com o tom autobiográfico da obra, o filósofo diz, na segunda parte (DA I, p. 568-78), que o intento de suas reflexões nunca fora "além de procurar reformar meus próprios pensamentos, e construir um terreno que é todo meu". Cheio de cuidados, adverte que "mesmo tendo minha obra me agradado bastante", nem por isso queria "aconselhar alguém a imitá-lo". E é enfático em rejeitar totalmente "esses temperamentos perturbadores e

14. Esse ponto de vista é defendido por Goyard-Fabre, 1973, p. 319 e 333. Tuck emite opinião no sentido inverso (mas, a meu ver, igualmente equivocada): que Descartes sustenta um pragmatismo político (dai a sintonia com Maquiavel) exatamente porque não encontra uma via segura de construção de uma moral positiva, permanecendo cético nesse terreno (cf. 1988, p. 247-8). Un cotejo mais detalhado entre as teorias morais de Descartes e Hobbes - que, malgrado todas as diferenças entre os dois filósofos, têm muitos pontos de contato - ainda está por ser feito.

15. Sobre o apoliticismo do pensamento estóico e epicurista, que me parece ter vários paralelos com o de Descartes, ver as interessantes reflexões de Strauss, 1953, cap. IV e V. 
inquietos que, não sendo chamados nem pelo nascimento nem pela fortuna, ao manejo dos negócios públicos, não deixam de neles praticar sempre, em idéia, alguma nova reforma". Uma posição tão contrária à ação reformadora (no campo político e dos "costumes") não implica, naturalmente, que quem adere a ela deixe de escrever sobre o assunto. Mas, na sexta parte do livro (DA I, p. 632-50), trata de dissipar essa dúvida: enquanto considerou seu dever publicar os resultados a que chegara no campo das "ciências especulativas" (especialmente "noções gerais de Física") "Pois elas me fizeram ver que é possível chegar a conhecimentos que sejam muito úteis à vida"; teve o cuidado de nada escrever sobre os "costumes", já que "cada qual segue de tal forma o seu próprio parecer que se poderia encontrar tantos reformadores quantas cabeças, se fosse permitido a outros, além dos que Deus estabeleceu como soberanos dos povos, ou então aos que concedeu suficiente graça e zelo para serem profetas, tentar mudá-los em algo".

Vê-se quanto esses pensamentos (escritos em 1637) ainda estão presentes em Descartes quando da primeira carta sobre Maquiavel. Mas há algo especialmente comum nos dois escritos: embora a carta admita explicitamente "príncipes novos" (o que significa admitir que um aventureiro, um particular, possa eventualmente alçar-se ao poder), possibilidade que o texto do Discours parece rejeitar, ambos expõem a necessidade de uma instância que governe a sociedade e seja distinta dela, de uma pessoa ou grupo de pessoas que dite a justiça aos outros homens sem qualquer contestação.

Mas Descartes, em vez de usar essa idéia como "semente" de uma filosofia política (como acontece em Hobbes), vai usá-la estritamente como "semente" de sua moral. Pode-se até considerá-la como um dos "fundamentos" desta, e que vai colocar ao lado de três outros "fundamentos" que apresenta à princesa Elisabeth, numa carta de 1645: somos todos "uma parte deste Estado, desta sociedade, desta família [e] não saberíamos subsistir sozinhos" (DA III, p. 607). ${ }^{16}$ Se é assim, uma instância de governo se impõe para impedir que o mau uso do livre-arbítrio de alguns prejudique os que 0 usam bem e acabe pondo em perigo a própria sociedade. Mais do que isso: a primeira máxima da "moral provisória" do Discours: "Obedecer às leis e aos costumes de meu país", tacitamente assume a impossibilidade de considerar que as "leis e costumes" de um determinado país sejam superiores às de qualquer outro, aceitando assim sua irredutível diversidade (cf. DA I, p. 583). Não há um fundamento universalmente válido para a justiça; aliás, bem de acordo com o que escrevera na carta sobre Maquiavel. Nem há qualquer tentativa de demonstrar a superioridade de regimes absolutos. Há sim um esforço de identificar um seguro "fundamento" da máxima moral (e apenas moral) que estabelece a necessidade de se obedecer às leis e ao governo do país em

16. Os outros três "fundamentos" são: a) Que há um Deus "cujas perfeições são infinitas, cujo poder é imenso, cujos decretos são infaliveis"; b) Que a alma é distinta do corpo, e é "mais nobre" que ele; c) Que não devemos prejulgar a respeito dos fins das "obras" de Deus. O fato de Descartes se referir a estes três princípios como "fundamentos" deve-se, como ficará claro em seguida, à sua tentativa de enraizar as máximas da moral em sua Metafísica. 
que se está vivendo, seja ele monarquista ou republicano; esteja-se na França, Holanda ou Turquia, não importa: "meu país" é bem diferente de "minha pátria".

Outro ponto significativo da "moral provisória" do Discours é o que determina aceitar as opiniões "mais moderadas", ou seja, as que estejam mais equidistantes dos "extremos", conforme deixa claro o texto: tais opiniões, além de serem mais praticáveis, são "verossimilmente as melhores, pois todo excesso costuma ser mau", e provocam erros menores do que "tendo escolhido um dos extremos, fosse o outro o que deveria ter seguido". O que contrasta nitidamente com sua aprovação ao preceito maquiaveliano contra a via del mezzo, na carta em que se refere aos Discorsi. Porém, não se trata de uma mudança de posição sobre as máximas de sua moral, e sim de uma mudança de objeto de reflexão.

No Prefácio aos Principes de la philosophie, dedicado à princesa Elisabeth, o sentido de "moral provisória" se amplia um pouco; perde o traço marcadamente pessoal em que é apresentada no Discours e passa a ser proposta a todo homem que queira trilhar, como ele, o caminho da sagesse, o da aquisição de "um perfeito conhecimento de todas as coisas que o homem pode saber". Mas a idéia de provisoriedade da moral se mantém, como pode ser constatado no momento em que lança mão da famosa imagem da "árvore da filosofia". É nesta passagem, aliás, que somos mais inclinados a pensar a filosofia cartesiana como um sistema, como um conjunto de disciplinas que se relacionam umas às outras dedutivamente. Que disciplinas a integram? Primeiro, a Metafísica (=raízes), isto é, os "princípios do conhecimento"; segundo, a Física (=tronco), ou os "princípios das coisas materiais"; por último, "todas as outras ciências" (=ramos), redutíveis a "três principais": a Medicina, a Mecânica e a Moral. O caráter provisório de suas máximas morais é sugerido aqui, quando Descartes nos põe na expectativa de uma "perfeita Moral" ainda por vir: "entendo que a mais alta e perfeita Moral, pressupondo um inteiro conhecimento das outras ciências, é o último degrau da sabedoria (sagesse)" (DA III, p. 780).

A parte o problema da provisoriedade, do qual falarei em seguida, salta à vista que Descartes não mencione especificamente a Política ou o Direito. O que confirma, no mínimo, seu desinteresse por elas e sua intenção de não estender suas investigações para o mundo dos soberanos nem das "leis e costumes" dos povos. E sugere que a falta de um conhecimento específico delas não compromete a aquisição da sagesse. Também vale mencionar o fato de a Medicina e a Mecânica, duas disciplinas técnicas, estarem posicionadas no mesmo lugar da Moral, se considerarmos a imagem da árvore.

Afirmei, anteriormente, que a moral cartesiana tem por objeto a "felicidade de cada um". Esta é definida pelo "contentamento do espírito" obtido com a prática da vertu, o que simplesmente quer dizer "usar o entendimento o melhor possível". Quando Descartes diz "o melhor possível", está sinalizando que a união corpo/alma impossibilita a intuição das idéias claras e distintas. E que, portanto, as "idéias confu sas" integram o campo da ação humana substancialmente e não apenas acidentalmen- 
te, como acontece no campo especulativo (em que o uso preciso do método pode disciplinar a vontade de inclinar-se apenas ao que o entendimento determina como claro e distinto). Ora, no caso da moral, é preciso disciplinar a vontade para a ação apesar das idéias confusas. O entendimento não tem como conhecer de modo absolutamente certo; só há conhecimento verossímil. Com isso o problema passa a ser, não a ausência de ciência, mas a irresolução ${ }^{17}$ - por isso, no Discours, é parte sistemática de sua filosofia a adoção de uma "moral provisória" enquanto a dúvida perdure.

É certo que no Discours e no Prefácio dos Principes, Descartes coloca o leitor na expectativa de uma moral "mais perfeita". A meu ver, isso não implica a expectativa de uma moral definitiva, no sentido de uma ciência apodítica, pois que estaria em expressa contradição com a metafísica cartesiana. A moral jamais será uma ciência - no sentido estrito de conhecimento absolutamente certo, como o são a Metafísica e a Física - pois a própria natureza do objeto impede essa possibilidade. Neste sentido, a moral é definitivamente provisória. Ela pode, sim, ser aperfeiçoada, já que um conhecimento verossímil pode ser substituído por outro mais verossímil (daí que a moral do Discours e do Prefácio dos Principes seja "provisória"). ${ }^{18}$

Embora a ação não receba o selo de garantia das idéias claras e distintas, a moral (enquanto uma técnica) tem "fundamentos" certos. Ela é um ramo da árvore, suas raízes são metafísicas - garantia da existência de um Deus, que a alma é mais nobre que o corpo e a impossibilidade humana de se conhecer as causas finais da criação divina. O conhecimento dos "fundamentos" abre o caminho da felicidade. Pois, apontando que os bens da alma são mais importantes que os do corpo (mesmo estes são gozados na alma e não no corpo em si), concluímos que o libre arbitre é o maior bem que possuímos; que seu bom uso exige apenas bon sens, do qual todos somos dotados; que, mesmo que o entendimento erre - o que é sempre possível no campo da ação -, ainda assim o espírito pode se contentar pelo esforço de ter agido o melhor possível. E, apontando que há um Deus cujos decretos são "infalíveis", concluímos que nenhum infortúnio ou desastre pode ser tão grande que supere o contentamento de ver realizada a vontade de Deus (cf. DA III, p. 599-609).

Mesmo que nessa passagem - como em muitas outras - o filósofo empregue 0 termo fortuna, entende-a como uma "falsa crença", baseada num erro do entendimento. À fortuna Descartes opõe o termo providência divina, conforme aponta nas Passions: a providência é "como uma fatalidade ou uma necessidade imutável que cumpre opor à fortuna, para destrui-la como uma quimera que provém apenas do erro de nosso entendimento", pois a crença na fortuna advém do fato "de não conhecermos todas as causas que contribuem para cada efeito" ( $P A$, art. 145). Quem está preso a essa crença, está sob o "império da fortuna", sempre desejará coisas que não dependem de si, ou melhor, não estabelece aquela distinção entre o que depende de

17. Sobre a "irresolução", ver DA I, p. 591 e DA III, p. 599-604.

18. Sobre o problema da "moral provisória", ver Teixeira, 1990, p. 127-50, e Gueroult, 1968, cap. XX. Nesses textos 0 leitor vai encontrar uma interpretação para o problema que vai na mesma direção (e exposta com mais detalhe) da apontada no presente artigo. 
mim e o que não depende, logo, os "desejos vãos". Entretanto, aquilo que depende de meu livre-arbítrio eu devo fazer, pois minha ação livre faz parte da concatenação universal das coisas, é mais uma causa entre outras: se Deus nos concedeu o poder de escolher, então escolher livremente é um dever. Daí Descartes não opor providência a livre-arbítrio, mas insista em opô-la à fortuna.

Se no Prefácio dos Principes a "moral provisória" ainda parece destinada a todo homem que queira adquirir a sagesse - e esta tem ali uma tendência a ser identificada com "conhecimento científico" -, nas Passions e particularmente na correspondência com Elisabeth e a rainha Cristina da Suécia, emerge o pensamento de que a moral é o meio para a obtenção da felicidade de todos os homens enquanto indivíduos: "não há quem não deseje tornar-se feliz", diz ele; o problema é que "muitos não conhecem o meio" (DA III, p. 600). ${ }^{19} \mathrm{E}$ o meio é o conhecimento de algumas poucas verdades acessíveis a qualquer homem de bon sens, mesmo àquele que não queira trilhar 0 árduo caminho do conhecimento científico. Fora esses poucos conhecimentos - que permitem traçar a fronteira entre o que depende de mim e o que não depende -, todo o resto do trabalho é da vontade, que faz com que desenvolvamos hábitos adequados e uma técnica para monitorar os desejos (o que Descartes diz, nas Passions, ser a "principal utilidade da moral" - cf. PA, art. 144). A sagesse ganha, portanto, um sentido, digamos assim, mais laico.

Compreende-se agora por que o filósofo perfila Medicina, Mecânica e Moral, todas elas técnicas enraizadas na Metafísica e na Física; e por que a Política não se enquadra na imagem da árvore.

É verdade que a Medicina e a Mecânica não enfrentam o problema da união substancial, pois seus objetos são corpos puros; enquanto a Moral diz respeito ao corpo apenas unido à alma. E, portanto, o entendimento puro tem maior possibilidade de interferência sobre os primeiros, já que voltamos a encontrar pelo menos uma idéia clara e distinta (a da extensão). Podemos conhecer perfeitamente as causas do movimento dos corpos inanimados e do funcionamento do corpo humano (considerado agora estritamente como animal-machine) e, por experiências adequadas, produzir deste conhecimento causal os efeitos que desejarmos. Neste sentido, são técnicas que procuram diminuir a zero a dependência com o fortuito e o casual. E nos encaminham, com segurança, para a obtenção de meios que "permitiriam gozar, sem qualquer custo, os frutos da terra e todas as comodidades que nela se acham (DA I, p. 634). Contudo, guardada essa diferença de nível epistêmico, Medicina, Mecânica e Moral vão se encontrar no plano antropológico, quando entra em cena a idéia da felicidade enquanto "gozo do espírito". Pois não é justamente esse o objeto de sua Moral, mesmo que no limite - isto é, quando não for possível gozar senão o uso do livre-arbítrio - Descartes tenha que compatibilizar felicidade com resignação ou conformismo? Por mais paradoxal que isso pareça, o viés estóico da moral cartesiana acaba cruzando com o ideal epicurista da ação técnica.

19. Ver, a respeito, a análise de Teixeira, 1990, p. 130-6. 
Uma leitura atenta da correspondência com a princesa sobre a moral vai constatar, por exemplo, uma preocupação básica com o gozo resultante da posse do Bem Supremo. Vemo-lo então distinguir Bem Soberano e beatitude: "a beatitude não é o soberano bem; mas o pressupõe, e ela é o contentamento ou satisfação do espírito que vem do fato de o possuirmos". Ora, quanto ao fim de nossas ações, diz, "pode-se entender um e outro", já que, embora o Bem Soberano seja o "escopo de todas as nossas ações", o contentamento do espírito é "o atrativo que nos incita a procurá-lo" (DA III, p. 592-8). Sim, a prática da virtude é imprescindível à felicidade; mas porque possibilita a maximização do "contentamento" nesta vida. ${ }^{20}$

Eis como Descartes consegue encontrar, no campo da ação, da mistura inseparável da alma e do corpo, um lugar (por mais estreito que seja) para o uso seguro da razão - um uso que não fruste e, ao mesmo tempo, dependa de cada um; que possibilite, enfim, um refúgio tranqüilo, mesmo na mais terrível tempestade dos negócios humanos.

Eis também por que Descartes, apesar de não considerar sua moral uma ciência no sentido estrito, pôde integrá-la à sua filosofia.

Quanto à ética, parece-me que a principal dificuldade que encontra para dar-lhe status filosófico é a mesma que o leva a estipular uma das máximas da "moral provisória" do Discours, isto é, a constatação da enorme variedade de "leis e costumes" existentes no mundo, sem que se possa apontar um sistema privilegiado ou um fundamento comum: "todos esses que têm sentimentos muito contrários aos nossos, nem por isso são bárbaros ou selvagens, mas muitos usam da razão, tanto ou mais que nós" (DA I, p. 583). Daí o filósofo poder ter encontrado um "fundamento" para a necessidade de se viver em sociedade e sob governos e, ao mesmo tempo, ter deixado na completa indeterminação qual ou quais devem ser os tipos de governo e quais devem ser os seus princípios legais. Esta seria uma tarefa que Deus abandonara aos habitantes dos diferentes países, e que nenhum filósofo poderia avocar para si, no sentido de universalizá-la, sem que acabasse vítima de seus próprios preconceitos.

Já a ação política (em sentido estrito), a contrário da moral, nos atira ao "império da fortuna". Mesmo que tenhamos certeza da concatenação universal das coisas, aventurar-se nela implica uma vinculação à ação dos outros e a acontecimentos raramente dependentes de nosso controle: em relação às máximas dessa matéria, diz Descartes numa carta à princesa (maio de 1646),

vale melhor se regrar sobre a experiência que sobre a razão, pois que raramente pode-se tratar com pessoas perfeitamente razoáveis, assim como todos os homens deveriam ser, a fim de que se possa julgar sobre o que farão, apenas pela consideração do que deveriam fazer; e freqüentemente os melhores conselhos não são os mais felizes. Por isso se é constrangido a arriscar (hasarder) e se colocar ao poder da fortuna. (DA III, p. 653-4)

20. Insisto em "nesta vida": Descartes não está falando da felicidade de uma vidafutura, pós-morte, mas da felicidade terrena. Cf. DA III, p. 709-24. 
Em síntese, a ação política dilui a fronteira entre o que depende e o que não depende de mim. Ora, obstruir esse conhecimento é obstruir a própria ação ditada pela vraie raison. Aqui está o ponto: Descartes faz um recorte no interior do campo prático que lhe permite definir uma racionalidade (diferente, é claro, da racionalidade no domínio especulativo), mesmo quando o entendimento não tem diante de si senão "idéias confusas": é o recorte entre a ação voltada para a "felicidade" e a ação entregue ao "império da fortuna". A "verdadeira razão" dita que cada qual deve buscar sua própria felicidade. $\mathrm{E}$ a felicidade depende do conhecimento dos fins, ao qual estão associados a distinção entre o que depende e o que não depende de mim, o controle da vontade sobre o desejo, o "contentamento" obtido pelo exercício da virtude etc. A ação entregue ao "império da fortuna" pode até ser "razoável" ou "eficaz" no sentido de adequar convenientemente meios a um fim qualquer. Mas não é isso que Descartes tem em vista. Pois a ação moral leva à felicidade, mesmo quando não é eficaz, assim como a ação do príncipe pode ter eficácia, sem que isso signifique dar um só passo rumo ao Bem Supremo.

Não é casual, portanto, que o filósofo procure mostrar à princesa que a condição privada a que ela se viu reduzida com a Guerra dos Trinta Anos, ao contrário de dificultar, facilitou-lhe encontrar o caminho da "vida feliz":

Não poderia ir a um tempo mais vantajoso para me fazer bem reconhecer a felicidade da vida tranqüila e retirada, e a riqueza das mais medíocres fortunas. Se Vossa Alteza compara sua condição com a das rainhas e outras princesas da Europa, encontrará a mesma diferença que entre esses que estão no porto, onde repousam, e esses que estão em pleno mar, agitados pelos ventos de uma tempestade. (DA III, p. 867-8)

ARAUJO, C. Some reflections on Descartes and Maquiavelli. Trans/Form/Ação, São Paulo, v. 17, p. 113-132, 1994.

- ABSTRACT: In this paper two Descartes' letters on Machiavelli are examined. Firstly, following the philosopher's own suggestions in the letters, Descartes' and Machiavelli's thoughts are contrasted, from which a distinction between Morals and Politics (in Descartes) arises. Next, the Cartesian Morals is explained in order to point out the roots of this distinction.

- KEYWORDS: Descartes; Machiavelli; Morals; virtue; Politics; fortune. 


\section{Referências bibliográficas}

1 DESCARTES, R. Oeuvres completes. Paris: Vrin, 1966. 2 v.

2 . Obra escolhida. Trad. J. Guinsburg e B. Prado Júnior. São Paulo: Difel, 1973.

3

4 Oeuvres philosophiques. Paris: Garnier, 1983.

1984. . Carta de Descartes. Trad. A. R. Nascimento. Trans/Form/Ação, v. 7, p. 61-8,

5 GOYARD-FABRE, S. Descartes et Machiavel. Revue de Metaphysique et Morale, p. 312-34, jul./sep., 1973.

6 GUEROULT, M. Descartes selon l'ordre des raisons. Paris: Aubier-Montaigne, 1968.

7 LEFORT, C. Le travail de l'oeuvre: Machiavel. Paris: Gallimard, 1972.

8 MAQUIAVEL, N. Comentánios sobre a primeira década de Tito Lívio. Trad. S. Bath. Brasília: Editora da UnB, 1979.

9 . O príncipe. Trad. L. Xavier. São Paulo: Nova Cultural, 1987.

10 POLIN, R. Descartes e a filosofia política. Trad. C. A. R. do Nascimento et al. Cademos PUC, São Paulo, n. 27, p. 53-71, 1987.

11 REGNAULT, F. La pensée du prince (Descartes et Machiavel). Cahiers pour l'Analyse, Paris, n. 6, p. 21-62., s.d.

12 STRAUSS, L. Natural nights and history. Chicago: The University of Chicago Press, 1953.

13 TEIXEIRA, L. Ensaio sobre a moral de Descartes. São Paulo: Brasiliense, 1990.

14 TUCK, R. Optics and sceptics: the philosophical foundations of Hobbes' political thought. In: Conscience and casuistry in early Modem Europe. Cambridge: Cambridge University Press, 1988. 